\title{
Was there a Political Dimension to the Irish Rockite Movement of 1821 to 1824 ?
}

\author{
Rebecca Preston
}

\section{Abstract}

The Rockite movement was one of the most violent agrarian rebellions in Irish history, renowned for its use of incendiarism and murder to achieve a basic form of political mobilisation. The Rockite movement, along with other pre-famine agrarian rebellions, was traditionally perceived to be motivated by purely localised socio-economic tensions. Through analysing the famous Rockite notices and contemporary newspaper commentary of Rockite attacks, it is evident that the Rockites were a complex and unique movement, transcending more orthodox understandings of social banditry. The Rockites were motivated by a strong sense of political agitation and significantly influenced contemporary, as well as post-famine politics. The violent and conspiratorial tradition of the Rockites continues to resonate with modern paramilitary organisations in Ireland.

The Irish Rockite movement of 1821 to 1824 was characterised by sustained agrarian violence and the use of intimidating documents by Irish agrarian rebels. The Rockites were named after their mythical leader Captain Rock and dominated southern Ireland throughout the early nineteenth century. Due to Daniel O'Connell's high profile constitutional movement for Catholic emancipation throughout 1823 to 1847, pre-famine agrarian rebellions have traditionally been viewed as apolitical and led by lower class social bandits who were motivated purely by localised socio-economic tensions. SJ Connolly, for example, argued that the Rockite movement was 'primarily a pragmatic, even conservative, movement, concerned with limited and specific' economic-based goals, including the regulation of rents, wages and tithes, the protection of poor tenants threatened with eviction and wider access to land for tillage. ${ }^{1}$ Connolly dismissed the notion that the Rockites were motivated by political agitation, concluding that the Rockite movement was 'not radically different from other

1 SJ Connolly, 'Mass Politics and Sectarian Conflict, 1823-30' in WE Vaughan (ed.), A New History of Ireland, V: Ireland Under the Union, 1: 1801-70 (Oxford, 1989), 81. 
agrarian protests of the early nineteenth century'.$^{2}$ Eric Hobsbawm similarly contributed to the romanticised conception of Irish agrarian rebels as merely lower class bandits agitating for improved economic circumstances. In his book Bandits, Hobsbawm viewed social banditry as a common trait inherent within all rural societies in 'old-established and permanent pre-industrial empires'. He argued that such societies, including Ireland, have long developed traditions of 'unofficial political systems and networks', which often reached 'out to all who were outside and against the official structure of power, including both social bandits and the outsider groups'. He claimed that only those organisations that had strong community alliances and resources could be described as effective political rebels, rather than mere social bandits. ${ }^{3}$ To an extent, the Rockites conform to Hobsbawm's conception of banditry, as members of the Rockite movement were often poor outsiders refusing to 'accept the normal rules of poverty' and in opposition 'to the hierarchy of power, wealth and influence' of Ireland. ${ }^{4}$ Conversely, the Rockites challenge Hobsbawm's homogenised definition of social bandits, as the complex movement was supported by a multiplicity of social classes and was motivated by traditional economic grievances as well as political and religious factors. The Rockite movement demonstrates that the distinction between social bandit and political leader is often blurred.

This essay challenges the orthodox view put forward by Connolly and Hobsbawm, by proposing that the Rockites were significantly influenced by contemporary politics and played a central role in pre-Famine Irish political life..$^{5}$ It argues that the Rockite movement had a strong political dimension as they were perceived as a political threat by the British Government and were partially motivated by political grievances. It is acknowledged that the Rockites were not solely motivated by political agitation - the movement encompassed a multifaceted agenda. The myriad motivations, however, including economic, ideological, political and religious, were interconnected and contributed to the politicisation of the Rockites. This essay aligns more closely with the arguments proposed by Tom Garvin, Shunsuke Katsuta and James Donnelly. Although focusing on the secret society of the Ribbonmen, Garvin highlights the important political role secret societies played in pre-Famine Ireland, arguing that the Ribbonmen 'showed distinct signs of politicisation' and formed an important 'connecting link with the revolutionary nationalist societies' of the eighteenth century. ${ }^{6}$ Katsuta engaged in a localised study of the Rockites, focusing on the political, millenarian and agrarian dimensions of the Rockite

2 ibid., 82.

3 Eric Hobsbawm, Bandits (Great Britain, 1969; Revised Edition; Great Britain, 2000), 42.

4 Eric Hobsbawm, 'Social Bandits: Reply', Comparative Studies in Society and History, 14 (1972), 504.

5 The term 'political' is used in reference to systems of government, state policies, and ideologies relating to state power.

6 Tom Garvin, 'Defenders, Ribbonmen and Others: Underground Political Networks in Pre-Famine Ireland', Past \& Present, 96 (1982), 134. 
movement in County Cork. ${ }^{7}$ Through his numerous articles and books, Donnelly provides the most comprehensive historiographical contribution to the history of the Rockites. Donnelly particularly stressed the sectarian and millenarian dimensions of the Rockite movement, arguing that Pastorini's prophecies (expounded in Bishop Charles Walmesley's book The General History of the Christian Church, published under the pen name of Signor Pastorini ${ }^{8}$ ) 'helped to rally Catholic country people to the Rockite cause' ${ }^{9}$ He similarly recognised the political features of the Rockite movement, but cautions that he does not believe the 'Rockite movement was predominantly political' ${ }^{10}$ Unlike other historical works, this essay exclusively analyses the Rockite movement from a political perspective. By doing so, it is evident that the actions and motivations of the Rockites significantly influenced the political history of post-Famine Ireland, particularly the nationalist and sectarian violence which plagued twentieth century popular politics. The violent and conspiratorial tradition of secret societies continues to resonate with modern paramilitary organisations, such as the Irish Republican Army (IRA) and Ulster Volunteer Force (UVF), which are still active in Northern Ireland today.

This essay begins with a brief overview of the secret societies in Ireland, the origins of the Rockites and the economic circumstances which significantly influenced the Rockite movement. The political dimension of the Rockite movement is demonstrated firstly through analysing the nationalist and antiEnglish language of Rockite notices and the promulgation of Rockite regulations. Secondly, this essay assesses the Rockites' use of symbolic violence to target Protestant clergymen, particularly those representing the Church of England, and representatives of the British state. It also analyses British responses to such violence through the introduction of specialised British laws and the army. Finally, this essay recognises, as Donnelly stresses, the importance of millennialism and sectarianism to the Rockite movement, but goes further to propose that the religious influences of millennialism and sectarianism were largely politicised, as the Rockites viewed Protestantism and the British state as the ultimate cause of Catholic poverty and oppression. Contemporary newspapers, predominantly The Times, Dublin Evening Post and the Morning Chronicle are drawn on to provide evidence of political motivations and details of Rockite actions, as newspapers frequently published Rockite notices.

The phenomenon of secret societies was a peculiarly Irish response to social and political grievances. Secret societies flourished in rural Ireland, particularly in the southern counties, between 1760 and 1845 when they came to be central

7 Shunsuke Katsuta, 'The Rockite Movement in County Cork in the Early 1820s', Irish Historical Studies, 33 (2003), 279.

8 James S. Donnelly, Jr., Captain Rock: The Irish Agrarian Rebellion of 1821 - 1824 (Madison, 2009), 122.

9 ibid., 10.

10 ibid., 22. 
to pre-famine political life in Ireland. ${ }^{11}$ Particularly in the 1820s, the height of the Rockite movement, Irish popular politics was significantly influenced by violent underground movements. ${ }^{12}$ These multifaceted societies had their own agenda, motivations, tactics and class composition. The Caravats, for example, were a unified rebel group of lower class rural labourers and farmers, whilst the Shanavests were primarily of middle-class origins. Common to all societies was the use of agitation, intimidation and violence by agrarian rebels to achieve a basic form of political mobilisation. The Rockite movement constituted one of the most extensive and violent agrarian rebellions in pre-famine Ireland, renowned for its frequent use of incendiarism and murder as weapons of warfare.

The Rockite movement began in the west of County Limerick in 1821, following the assassination of the son of Alexander Hoskin - the land agent of the Viscount Courtenay's 34,000-acre estates. ${ }^{13}$ Hostilities towards Hoskin were accentuated after he increased the tenants' annual rent by 40 per cent. ${ }^{14}$ Following the assassination, small groups of rebels began to raid towns in counties Cork, Limerick and Kerry, acquiring arms and ammunition. Dublin Castle, which served as the administrative centre for the British Government, army and police, immediately dispatched police forces, troops, yeomanry corps and veteran battalions to repress the escalating disturbances. These measures forced the first Captain Rock, leader and assassinator of Hoskin's son, Patrick Dillane, to flee into undeveloped rural land. ${ }^{15}$ Dillane was a blacksmith from the Shanagolden district and was a tenant of Lord Courtenay's estate during Hoskin's tenure as agent. ${ }^{16}$

From 1821 onwards there is evidence of secret Rockite societies forming across the province of Munster through the swearing of oaths. Similar to other secret societies such as the United Men, Ribbonmen and the Caravats, members of the Rockites were sworn by an initiation oath which contained vows of sectarian and political nature. ${ }^{17}$ The vows were intended to safeguard against betrayal by forcing Rockite members to swear allegiance to the movement and to assist in destroying all non-Catholic heretics and oppressors. ${ }^{18}$ Despite the common Rockite oath, it remains unclear to what extent the various Rockite groups across Munster were coordinated and organised as a common underground organisation.

11 Samuel Clark and James S Donnelly, Jr, 'Introduction', in Samuel Clark and James S Donnelly Jr (eds),

Irish Peasants: Violence and Political Unrest 1780-1914 (Madison, 1983), 65-66.

12 Garvin, 'Defenders, Ribbonmen and Others', 133.

13 Katsuta, 'The Rockite Movement in County Cork', 279.

14 James S Donnelly Jr, 'The Origins of the Irish Agrarian Rebellion of 1821-24', New Hibernia Review, 11 (2007), 52.

15 Katsuta, 'The Rockite Movement in County Cork', 280.

16 Donnelly, 'The Origins of the Irish Agrarian Rebellion', 56.

17 Donnelly, Captain Rock, 97.

18 ibid. 
A unique feature of the Rockite movement was the complexity and diversity of its social composition and the widespread support it received from all classes in rural Ireland. Both wealthier, middle-class farmers, as well as poorer farmers, labourers, artisans and cottiers from southern and south-west Ireland, were represented among Rockite supporters and leaders. This broad social composition of the movement was unique among agrarian rebellions. ${ }^{19}$ Donnelly argues that 'there were certain grievances that promoted social cohesion across class lines below the elite, just as there were other grievances that gave rise to acute conflict between one non-elite social group and another' ${ }^{20}$ Thus, the level of social cohesion or disunity between Rockite groups fluctuated depending on the economic conditions and nature of the landlord-tenant relations in a particular district. This enhanced cross-class collaboration was a product of the Rockites' alliance with Pastorini's millenarian prophecies, the use of sensational violence and contemporary economic depression, which resulted in tithe and rent grievances being pushed up the social scale. The intensity of the economic depression between 1821 and 1824 brought substantial economic hardship to once prosperous farmers and graziers. Donnelly suggests that this 'burning sense of economic injustice' primarily accounts 'for the diverse social composition of the Rockite movement'. ${ }^{21}$

The contemporary economic circumstances influenced the Rockite movement by engendering political agitation, millennialism and sectarianism. The series of economic crises in early nineteenth century Ireland aroused widespread discontent among rural society, enabling the Rockite movement to thrive and grow to maturity. The primary grievances of the Rockites were a product of the economic and agrarian climate of the early nineteenth century. The conversion of grassland, which was largely or completely tithe free, to sites of grain production, resulted in increases in taxes. ${ }^{22}$ In Munster and Leinster, tithes were charged on potato crops at the highest rates per acre. ${ }^{23}$ These areas coincided with a greater prevalence of Rockite violence. During 1819 to 1823, Ireland experienced a collapse in agricultural prices, particularly grain and livestock. This was partly due to the fact that the Irish economy was almost exclusively dependent on the British market, resulting in full exposure to British post-Napoleonic war price deflation and fluctuation. ${ }^{24}$ Donnelly noted that the plunging prices of grain and livestock alone were sufficient to incite widespread agrarian rebellion. ${ }^{25}$ This economic depression was exacerbated by the fever epidemic of 1816 to 1819 and the partial famine of 1821 to 1822 - both of which aroused fear and desperation

19 Donnelly, Captain Rock, 341.

20 ibid., 150.

21 ibid., 151.

22 Clark and Donnelly, 'Introduction', 30.

23 ibid

24 ibid., 31

25 Donnelly, Captain Rock, 340. 
among rural Ireland's population. ${ }^{26}$ The economic crises of the early nineteenth century enhanced cross-class collaboration between the landless and the landed and fostered widespread support for central Rockite grievances, particularly tithes, exorbitant rents, evictions and escalating food prices. ${ }^{27}$ The severity of the economic depression meant that discontent about rents and tithes were strongly felt by the wealthier farmers and graziers. Thus, agitation to regulate tithes and rents, and control the occupation of land became a primary concern of both poor and wealthy farmers. The Rockites' use of sensational violence further appealed to the masses.

The Rockites championed their interests through humiliating notices, threatening letters and violent attacks on property, predominantly through incendiary methods, and individuals, often beating, mutilating or murdering their victims. These extreme techniques were intended to display Rockite authority and incite fear throughout Ireland. Rockite violence was underscored by strong political symbolism, primarily through targeting representatives of the existing political system, including the Protestant clergy and the British army. By 1824 the movement had drastically dissipated, primarily as a consequence of the strong measures taken by Dublin Castle and the British Government.

The anti-English and nationalist sentiments espoused in Rockite notices demonstrate the influence of contemporary politics on the Rockite movement. In the first place, it is significant that the Irish-speaking peasantry used the English language in Rockite notices. The Rockites' use of English vocabulary was a political technique borrowed from the agrarian rebels of the 1790 s. $^{28}$ The Rockites expressed profound animosity towards British subjugation and political injustice to justify extreme violence. Evidence of anti-English resentment is demonstrated in a notice posted in County Tipperary:

We are pressed by the tyrannical laws of the English government ... to which they crowd us up with rent, tythes, and taxes ... English laws must be curbed in, for we will never be satisfied until we have the Irish parliament and king crowned in Ireland. ${ }^{29}$

The provocative and emotive language of this Rockite notice arouses antiEnglish sentiments and exemplifies the ways in which economic grievances

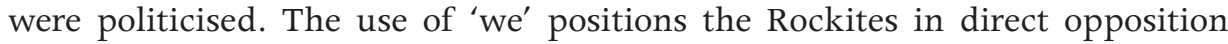
to the English, depicting themselves as a united, revolutionary force. This insurrectionary language was similarly employed in a notice posted outside Adare chapel in Limerick, which ordered the mobilisation of men 'in the name of the

26 ibid., 25, 340 .

27 ibid., 341.

28 Katsuta, 'The Rockite Movement in County Cork', 291.

29 Dublin Evening Post, 27 Dec. 1821. 
Irish' to march 'against the common enemy, the tyrant of Ireland, the English' in order to gain Irish independence. ${ }^{30}$ The juxtaposition between English tyranny and Irish freedom serves to create a sense of solidarity among the Rockites and legitimise their movement as representative of the Irish population. The explicit nationalist language revives the vision of the 1790s revolutionary movement. ${ }^{31}$ The anti-English and nationalist sentiments of Rockite notices were manifested through the articulation of their own standards of justice.

By promulgating their own laws and demanding strict adherence, the Rockites directly challenged the political authority of the Irish Government and the British Empire. After County Cork was declared under the operation of the Insurrection Act 1822, the Rockites sought to undermine the legal legitimacy of the state by posting a 'violent and inflammatory' notice on the chapel at Cloghroe. ${ }^{32}$ The notice proclaimed that inhabitants of County Cork should not pay tithes or taxes and all land taken within seven years must be surrendered. ${ }^{33}$ The Times reported that 'insurgents' attacked a 'respectable farmer' as he failed to surrender his farm in accordance with the notice. ${ }^{34}$ By promulgating laws and exacting punishment on lawbreakers, the Rockites mimicked and thereby challenged the established legal and judicial system. Rockite punishment often involved death or property destruction by incineration. A notice posted near Shambles, ordered that 'any person taking the contract for Soldiers' meat ... shall be met with fire and destruction' ${ }^{35}$ By targeting soldiers - representatives of the state - the Rockites imposed their political agenda on rural society, using intimidation to ensure their desires were achieved. The threat of violence consolidated Rockite power through manipulating the psychology of fear. This is highlighted in a notice sent to Mr Lamvert, the proprietor of the Kilnapp Iron Mills. Captain Rock threatened that if Lamvert failed to 'obey' his orders, he will be 'consumed to ashes and if not, you or any of your family shall be watched ... until you share the same fate which others have shared. ${ }^{36}$ Like political authorities, the Rockites enforced harsh punishments and used their victims as examples. ${ }^{37}$

The notice sent to Lamvert was also employed to champion a nationalist agenda, evidenced by Captain Rock's signature — '[signed] your sincere friend the brave and powerful Commander of the United Forces of Ireland'. ${ }^{38}$ By identifying Captain Rock as a 'Commander of the United Forces of Ireland', the

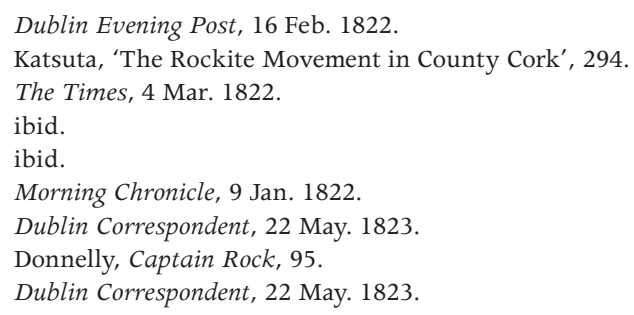


Rockites revived the language and vision of the revolutionary movement of the 1790s and created an image of a unified movement mobilised against political authorities. This image of the noble vigilante, addressing the grievances of the poor, was important in fostering widespread support and adding cohesion to the movement. This is illustrated in Captain Rock's letters to James Condon, ordering him to stop 'tyronizing over poor people ... and leave poor people their potatoes and turf' ${ }^{39}$ Through establishing their own regulations and advocating as a united force on behalf of the Irish poor, the Rockites presented a significant political challenge against British authorities.

Rockite violence was underscored by strong political symbolism, mainly by targeting representatives of the existing political system. Frequent violent attacks on property and individuals resulted in the mobilisation of all available resources by Dublin Castle to contain the Rockites. Special legislation was enacted to regulate rural disorder and political agitation. To restrict the use of intimidation and punishment by the Rockites and other secret societies, the British Government enacted the Whiteboy Amendment Act $1831^{40}$ and the Insurrection Act, which suspended habeas corpus and imposed a night curfew. ${ }^{41}$ Habeas corpus is a legal writ which requires an arrested person to be brought before a judge or jury in court, essentially protecting arrested persons from unlawful detention. The suspension of this writ resulted in trial without jury. The Insurrection Act was introduced in eight Irish counties; in Munster alone over 1500 men were trialled, of whom 200 were convicted and transported. ${ }^{42}$ The Unlawful Oaths (Ireland) Act 1823 and the Party Processions (Ireland) Bill ${ }^{43}$ were designed to repress sectarian violence, targeting both Catholic agrarian rebels and Orange societies. The Orange societies were a decentralised political organisation named after the Protestant William of Orange, King William III of Great Britain. In response to growing agitation for Catholic emancipation, the Orange Order, originally named the Orange Society, was formed in 1795 to maintain Protestant ascendancy. ${ }^{44}$ The introduction of British laws directly targeting agrarian violence highlights the direct political challenge the Rockites posed to the British state and British-Irish relations.

\footnotetext{
39 Morning Chronicle, 1 Dec. 1821.

40 The original title of the Act referred to is the Tumultuous Risings (Ireland) Act 1831, which is an amendment of the Tumultuous Risings Act 1775, commonly known as the Whiteboy Act (15 \& 16 Geo. 3. c. 21).

41 Virginia Crossman, 'Emergency Legislation and Agrarian Disorder in Ireland, 1821-41', Irish Historical Studies, 27 (1991), 309.

42 Katsuta, 'The Rockite Movement in County Cork', 278.

43 Hansard Debates of 1832 (HC Deb 25 June 1832 vol 13 cc1023-51). The Bill was referred to as the 'party processions act of 1832' in Virginia Crossman, 'Emergency Legislation and Agrarian Disorder in Ireland, 1821$41^{\prime}$, Irish Historical Studies, 27 (1991), 309.

44 The Orange societies continue to exist in Ireland and remain closely associated with Ulster Unionism.
} 
Rockite violence was also suppressed through the deployment of five British regiments, yeomanry and police. ${ }^{45}$ Lord Sidmouth, when acting as home secretary, admitted that the British army was deployed in southern Ireland to put down a 'most formidable Danger' ${ }^{46}$ The introduction of armed forces into southern Ireland exacerbated sectarian animosities and intensified campaigns of violence. ${ }^{47}$ The Rockites often targeted the yeomanry and British army as they represented Protestant ascendency and imperial subjugation - the perceived sources of Catholic destitution and economic oppression. Rockite attacks against the British military were most formidable in County Cork, with incendiarism occurring at a level 'unprecedented in the history of Irish agrarian disturbances' ${ }^{48}$ It is noteworthy that the Rockites did not exclusively target British and Protestant victims. Gale Christianson records that, despite the 'longstanding enmity between Catholics and Protestants', many agrarian rebels 'cut across the boundaries established by religious conviction' if it was necessary to achieve an ultimate goal, for example ending the tithe system. ${ }^{49}$ In addition, the Catholic clergy strongly condemned the tactics and violence employed by agrarian rebels - further exacerbating hostilities between Catholic peasantry and the Catholic Church. ${ }^{50}$ Yet overall, the Rockites primarily directed violence towards Protestant authorities and such attacks were underscored by strong political motivations. The yeomanry deployed in southern Ireland were associated with Protestant triumphalism as they participated in the Orange celebrations of the anniversary of the Battle of the Boyne - a politically charged event symbolising the beginning of British imperialism, Protestant ascendancy and the destitution of Irish Catholics. ${ }^{51}$

To reduce the risk of detection, the Rockites offered rewards to strangers to carry out violence, evidenced by the letter received by a sergeant of the Adare yeomanry. Captain Rock offered 'twenty pounds for every [yeoman] put to death; one hundred pounds for every officer; and fifty pounds for a serjeant $[\mathrm{sic}]{ }{ }^{52}$ By attacking representatives of the state, the Rockite movement became intrinsically political. Furthermore, the Rockites frequently exacted violent punishments whilst dressed as women, referring to themselves as 'Lady Rock' ${ }^{53}$ A similar phenomenon occurred in other secret societies, with the Whiteboys producing Lady Clares and Molly Maguires. ${ }^{54}$ By reversing gender identities,

45 Donnelly, Captain Rock, 344.

46 Lord Sidmouth, 23 October 1821, quoted in Katsuta, 'The Rockite Movement in County Cork', 278.

47 Donnelly, Captain Rock, 268.

48 Katsuta, 'The Rockite Movement in County Cork', 278

49 Gale E Christianson, 'Secret Societies and Agrarian Violence in Ireland, 1790-1840', Agricultural History,

46 (1972), 375.

50 ibid.

51 Donnelly, Captain Rock, 139.

52 Caledonian Mercury, 8 Nov. 1821.

53 Dublin Evening Post, 5 Feb. 1822.

54 Donnelly, Captain Rock, 110. 
the Rockites inverted social and sexual roles, repositioning women 'on top' and transforming women's traditional role of motherly protector to vicious attacker. ${ }^{55}$ This gender inversion paralleled the repositioning of the lower class Rockites as political governors and legal authorities of rural Ireland. The cross-dressing could also reflect a broader critique of British-Irish relations, repositioning the feminine Hibernia to rule over masculine Britannia. The Rockites' use of targeted violence and cross-dressing reflects a rejection of contemporary society and the political system.

The Rockite movement was motivated by sectarianism and Pastorini's millenarian prophecies, which envisioned the obliteration of Protestant ascendency in Ireland in the year $1825 .{ }^{56}$ Religious divisions in Ireland were accentuated by political realities, as the legal system secured Protestant monopoly of landownership, government positions and the economy. Pastorini's Book of Revelations, which predicted the end of Catholic destitution through the destruction of Protestant dominance, resonated with rural Irish Catholics across all classes, adding cohesion to the Rockite movement. ${ }^{57}$ The strong religious and anti-Protestant undertone of the movement reduced the sharpness of class antagonism and enabled the Rockites to rally cohesive support among rural Catholics. ${ }^{58}$ This millennial upsurge in Ireland was a result of inflated agricultural prices, deep-seated sectarian animosities, the revival of aggressive Protestant evangelicalism in 1815 and the growing intensity of the tithe grievance. ${ }^{59}$ The exclusion of poor, Catholic peasants from the political apparatus of the state further popularised the millennial movement and led to the idealisation of the Rockites as an alternative political vehicle through which they could advance their common interests. ${ }^{60}$ The Rockites used millenarian rhetoric to dehumanise the Protestant population, thus allowing the Rockites to morally justify and legitimise the use of extreme violence and incineration against Protestant landlords, clergy and churches. The Morning Chronicle reported the destruction of the Anglican church of Knockane which was 'maliciously set on fire' as a threat to churchwardens to stop collecting tithes. ${ }^{61}$ The tithe grievance was central to the Rockites and demonstrates the interconnection of economic, religious and political motivations. The collection of tithes for the Church of Ireland fostered resentment among Catholics and Protestants as it represented British imperialism, enhanced economic destitution of the rural poor and, for

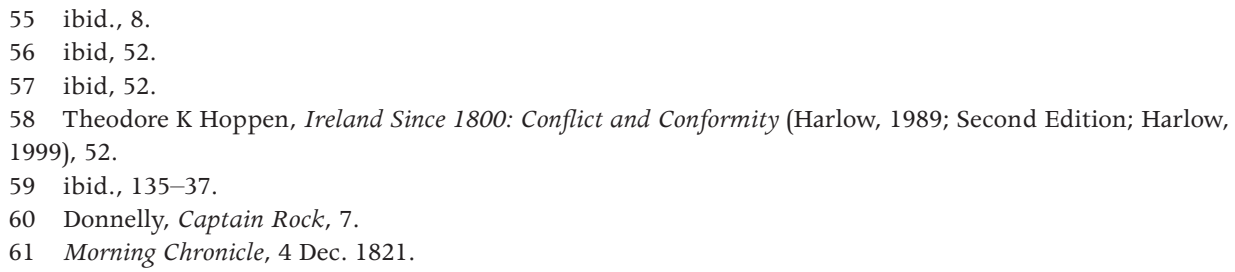


the Catholics, symbolised Protestant ascendency. ${ }^{62}$ A letter sent from Captain Rock to a Mr Hume highlights the centrality of tithes to Rockite violence and the politicisation of economic grievances. Joseph Hume (1777-1855) was a Scottish Member of Parliament who sat in the House of Commons. Hume was a strong advocate for free-trade principles and radical social reform. ${ }^{63}$ Captain Rock targeted Hume as he believed that Mr Hume was 'getting Parliament to do away with this curse-of-God tithe-law'. Captain Rock explained that 'houseburnings' and assassinations of ministers and tithe proctors were the only method of 'letting Parliament know that the savage tithe-law is galling us' ${ }^{64}$ Captain Rock further advocated for the repeal of the Insurrection Act and the restoration of habeas corpus, demonstrating the Rockites' use of threatening letters and violence as a vehicle of political protest.

The Rockites transcended traditional notions of social banditry and apolitical agrarian rebels. The Rockite movement had a strong political dimension, evident through the nationalist sentiments in Rockite notices and the promulgation of Rockite laws which undermined the legal and political authority of the state. Violence was often used as a vehicle of social and political protest, challenging Protestant and British ascendancy in Ireland. The politicised nature of the Rockites is also evidenced by Britain's response, namely the introduction of specialised laws and the deployment of armed forces. The frequent publication of Rockite notices in contemporary newspapers and British descriptions of the Rockites as malicious, notorious and savage, suggest that the Rockites were perceived as a substantial political threat.

\section{Bibliography}

\section{Primary}

\section{Newspapers}

Caledonian Mercury

Dublin Correspondent

Dublin Evening Post

Finns Leinster Journal

Freemans Journal

62 Donnelly, Captain Rock, 6.

63 The Times, 4 Mar. 1822.

64 ibid. 
The ANU Undergraduate Research Journal

Morning Chronicle

The Times

\section{Hansard Debates}

Hansard Debates of 1832 (HC Deb 25 June 1832 vol 13 ccl023-51).

\section{Secondary}

\section{Books}

Clark, Samuel \& Donnelly Jr, James S (eds), Irish Peasants: Violence and Political unrest 1780-1914 (Madison, 1983).

Connolly, SJ, 'Mass Politics and Sectarian Conflict, 1823-30', in WE Vaughan (ed.), A New History of Ireland, V: Ireland Under the Union, 1: 1801-70 (Oxford, 1989).

Donnelly Jr, James S, Captain Rock: The Irish Agrarian Rebellion of 1821-1824 (Madison, 2009).

Gibbons, Stephan Randolph, Captain Rock, Night Errant: The Threatening Letters of Pre-Famine Ireland, 1801-1845 (Dublin, 2004).

Hobsbawm, Eric, Bandits (Great Britain, 1969; Revised Edition; Great Britain, 2000).

Hoppen, Theodore K, Ireland Since 1800: Conflict and Conformity (Harlow, 1989; Second Edition; Harlow, 1999).

\section{Articles}

Campbell, Kenneth L, Ireland's History: Prehistory to the Present (London, 2014).

Christianson, Gale E, 'Secret Societies and Agrarian Violence in Ireland, 1790-1840', Agricultural History, 46 (1972), 369-84.

Crossman, Virginia, 'Emergency Legislation and Agrarian Disorder in Ireland, 1821-41', Irish Historical Studies, 27 (1991), 309-23.

Donnelly Jr, James S, 'The Origins of the Irish Agrarian Rebellion of 1821-24', New Hibernia Review, 11 (2007), 57-72.

Garvin, Tom, 'Defenders, Ribbonmen and Others: Underground Political Networks in Pre-Famine Ireland', Past \& Present, 96 (1982), 133-55.

Hobsbawm, Eric, 'Social Bandits: Reply', Comparative Studies in Society and History, 14 (1972), 503-05. 
Katsuta, Shunsuke, 'The Rockite Movement in County Cork in the Early 1820s', Irish Historical Studies, 33 (2003), 278-96.

Lagan Consulting, Northern Ireland Yearbook 2005: A Comprehensive Reference Guide to the Political, Economic and Social Life of Northern Ireland (Lisburn, 2004). 
This text taken from The ANU Undergraduate Research Journal Volume Five 2013, published 2014 by ANU Press, The Australian National University, Canberra, Australia. 